\title{
LESSONS FROM INTENSIVE EDUCATIONAL EXPERIENCES FOR ICT STUDENTS IN MULTINATIONAL SETTINGS
}

\author{
Luis Fernández, José Amelio Medina, María Teresa Villalba de Benito, Sanjay Misra
}

Original scientific paper

Real internationalization of education is the current challenge for students, teachers and universities in Europe after assuming the implementation of the EHEA (European Higher Education Area). The Erasmus programme has been playing a key role in exposing stakeholders to European internationalization. Although the large global figures of the programme are frequently analyzed, it is important to study the effects of the participation in exchange programs on students and teachers. Erasmus Intensive programs enable a closer look at the daily experience of students. In this article, we analyse the effects of intensive international programs on participants' perceptions and attitudes referred to international and multicultural working environments. Data for the analysis were collected through several experiences where ICT students were involved in intensive multinational programs. Results from 125 students using pre- and post- experience questionnaires show interesting benefits of participating in intensive experiences before starting longer or more challenging activities: they feel more motivated to be engaged in semester long staying or professional work abroad, less worries about how to work in multicultural settings, increment in self-confidence, etc.

Keywords: Bologna process; Erasmus program; higher education system; information base; students in informatics; study conditions

Pouke za ICT studente iz intenzivnih obrazovnih iskustava u multinacionalnom okruženju

Izvorni znanstveni članak

Stvarna internacionalizacija obrazovanja je trenutni izazov za studente, nastavnike i sveučilišta u Europi nakon provedbe EHEA (područja Europskog visokog obrazovanja). Program Erasmus je odigrao ključnu ulogu u izlaganju zainteresiranih za europsku internacionalizaciju. Iako se često analiziraju velike globalne brojke programa, važno je proučavati učinke sudjelovanja u programima razmjene na studente i nastavnike. Intenzivni programi Erasmusa omogućuju bolji uvid u svakodnevna iskustva učenika. U ovom članku analiziramo učinke intenzivnih međunarodnih programa na iskustva i stavove sudionika koji se odnose na međunarodna i multikulturalna okruženja. Podaci za analizu prikupljeni su od ICT studenata uključenih u intenzivne multinacionalne programe. Rezultati dobiveni od 125 studenata analizom upitnika provedenih prije i poslije sudjelovanja pokazuju zanimljive prednosti sudjelovanja u intenzivnim iskustvima prije započimanja dužih i izazovnijih aktivnosti: osjećaju se više motivirani da u inozemstvu ostanu na studiju ili na profesionalnom radu tijekom cijelog semestra, s manje brige o tome kako raditi u multikulturalnim okruženjima, s povećanim samopouzdanjem, itd.

Ključne riječi: Bolonjski proces; informacijske baze; Program Erasmus; studenti u informatici; studijski uvjeti; sustav visokog obrazovanja

\section{Introduction}

The reality of IT (Information Technology) professional activity and globalization implies computing students should face the challenge of working in multinational and multicultural environments as it will be part of the daily dynamics they will live in projects and companies. Globalization, multinational businesses and cultural awareness are widely accepted as key concepts in the business and professional world: they are simply accepted as a fact for life as OECD (Organisation for Economic Co-operation and Development) already realized in 2001 [1]. Developing cross-cultural competencies is critical for companies' success in order to compete globally as stated in [2].

Today, higher education is living a radical phase of internationalization as a reaction to the changes in global economy as shown in the detailed analysis by K. Guruz [3]. Activities abroad and international partnerships are playing a leading role as universities are imitating what multinational corporations are requesting or, at least, what globalization of markets and social trends are demanding. However, as stated in [4], even in countries like USA, the number of engineering students participating in study programs abroad in any year is rather low with an annual growth of $2 \%$. Moreover, engineering and IT students are especially concerned on how their degrees are connected to internationality: e.g. the study on attitudes and perceptions of Croatian students show they perceive lower satisfaction level with the connection to European recognition than students from other fields [5].
A typical beginning is to create exchange programs for students and teachers, normally through bilateral agreements. But this first step is not free of problems: a critical examination of the proliferation of these problems in international exchanges can be found at [6]. Of course, as a further step, organization of joint curricula among several universities offers a broader and more stable framework for international agreements, as is shown in many experiences [7, 8, 9].

In Spain, there is also a need of attracting international students as universities are pursuing transformation of campuses in multinational places. Universities also want to balance the decrease of national students as a result of demographical trends with students coming from abroad, as well as to overcome stringent economic conditions. At national level, universities are increasingly competing in the higher education market but they also need to compete at international level, going further from the mere interest in appearing in some tricky rankings which are too much focused on reduced research indicators.

Managers of universities (chancellors, rectors, deans, etc.) in Spain are clearly promoting this philosophy at a somewhat 'elite' level (initiatives generated and supported by higher management levels) [10]. However, there is a lack of permeation to basic levels as still important percentages of students and teachers (and especially administrative staff) do not perceive that their local environment is closer and closer to live a real multinational environment soon: reception of foreign students and teachers, lectures in English combining 
students of different cultures and nationalities, a continuous flow of outgoing and ingoing people, etc.

\section{Review of European exchange programs}

Fortunately, different options for helping in this process to internationalization were implemented many years ago in the European Union. These are currently helping students to experience multinational situations, especially in Europe. Erasmus programme (European Commission, 2005) is a cooperation and mobility program in higher education aimed at enhancing students and teachers' mobility in Europe while promoting intercultural understanding through co-operation of different countries. By far, it is the most known option by students, teachers and even society in general. The Erasmus programme offers university students the possibility to travel to another European country to study and do work placements (traineeships). A key factor is that these periods abroad contribute to qualifications at home through the recognition of credits in the corresponding degree. Of course, it also helps students get to know different cultures and languages as well as acquire live experience for their professional and personal development.

Erasmus concentrates really big numbers because millions of students have lived by the end of 2013 what one of these Erasmus periods (from 3 to 12 months) represents. So it is a reality that funding from EU Erasmus programme has helped many students to study abroad during a semester or a year. Statistics [11, 12] show impressive figures: 212522 students in academic year 2012-13 (last available statistics) studying abroad plus 55621 doing traineeships (placements) on other country (they were 144037 in 2004-05) totalling more than 3 million during the whole history of Erasmus.

However, this type of experience still represents a huge challenge for many students due to different reasons: funding, long lasting periods abroad with no previous experience, new learning cultures and styles, etc. This leads to a significant level of rejection to this type of experience of internationalization. Of course, getting that all students get a long lasting study period in another country is optimal, but unrealistic due to costs, time commitments, and other responsibilities. However, there is an alternative which might be considered as more convenient by many students as it represents a more guided option while it is also EU-funded: Erasmus Intensive programs (IP). This type of programs allows a more intensive exposure to work in multicultural environments. An IP is a short programme of study which brings together students and teaching staff from higher education institutions of at least three participating countries. It has to last a minimum of 10 continuous full days which can only be separated by weekends and national public holidays (although it is possible to extend it up to 6 weeks of subject related work). Normally an IP involves 6-7 universities from different countries. This type of project has to involve at least 10 students and 2 teachers per each university.

The dynamics of an IP requires that each university team has to work in their local setting on a topic or project defined by the academic staff. After that, everybody meet together during two weeks in one of the universities to present and discuss results, to work in multinational teams which merge together students of different universities: the idea is developing additional artefacts or documents, enjoying common social and cultural activities, sharing daily life in common accommodation premises, etc. During academic year 2012-13 [12] a good number of students (18 241) have participated in IP experiences which include a good variety of programmes (538) giving an average number of 34 students per IP and average duration of 12,5 days. Involvement of teachers in each IP reached an average number of 12 but the total number was 6658 in all programmes in 2012-13[12]. In general, IPs allowed recognition of an average of 5,25 ECTS for students in the subsequent credit recognition process in their local universities in 2008-09 [13] which it is compulsory in EU rules for funding these projects. In 2012-13 [12], some countries have awarded higher amount of credits: e.g. Ireland has an average of 10. IPs cover many subject areas but "science, mathematics and computing" was the thematic area with a $16 \%$ share during the period 2012 13 , while the highest one was "social sciences, business and law" (22\%).

Now the Eramus programme has been upgraded to Erasmus + with some small differences. Firtsly the new Eramus + is an aggregation of former programmes related to internationalization of educations like Leonardo, Eramus, etc. This is only a change pursuing a simplified centralized administration. The second change affects IP projects which are not longer explicitly supported as a specific modality although could be reproduced within other types of projects.

There are not many studies analyzing the effects of the Erasmus programmes (traditional or the plus one) on students' perceptions of mobility. However, some studies have really analyzed different aspects of the perception of participants regarding mobility and internationalization: e.g. in [14] authors compare results of classical Erasmus exchanges with classical economic reasons, family background, language and quality to explain proclivity to mobility and internationalization. Language issues are not considered barriers and even students tend to use mobility to improve their skills in foreign languages. In [15] the results of students" opinions in classical Erasmus experiences were positive, rating positively the cultural experience, the foreign language learning, the personal experience and the expected professional value of the temporary study period abroad although academic results were more modest. The benefits of Eramus exchanges for the future professional career of students were contrasted in a study in [16]. The conclusions of these studies encourage us to check if intensive experiences could achieve similar results and to analyze which are the effects on students in different relevant aspects

Within the context of the Erasmus programme, we present the results of several multinational intensive experiences developed as Erasmus IP projects as well as a couple of international seminars developed as cooperation agreements among several universities. All the experiences were developed in the subject area of computing and IT. Section 3 briefly presents the key aspects of these experiences with dates, locations and the 
figures of students, teachers and activities. Section 4 will present the data collected from tens of students and teachers through some questionnaires and other mechanisms. Section 4 discusses and analyzes results and suggests some learnt lessons while Section 5 outlines conclusions and future research actions.

\section{Intensive European and multinational experiences}

The series of multinational experiences covered by this article started in 2005 with a first Erasmus IP "Improving the success of the ICT projects Quality Assurance" (28991-IC-1-2003-1-NL-ERASMUSIPUC - 1) funded by the European Union. This first IP was coordinated by the Hogeschool van Amsterdam with the participation of the following higher education centers:

- Metropolia (former EVTEK Teknillinen Ammattikorkeakoulu), Espoo, Finland.

- Universidad Politécnica de Valencia, Spain.

- Hogskolen i Sor-Trondelag, de Trondheim, Noruega.

- Fachhochschule Vorarlberg GmbH, Vorarlberg, Austria.

- Mitthogskolan Mittuniversitetet (Universidad Media de Suecia), Sundsval, Sweden.

- Universidad Europea de Madrid, Spain.

This IP was celebrated two times: one in Amsterdam (2005) and another one in Sweden (2006). As a typical program, it included up to 10 students and 2-3 teachers per each center.

After these first experiences, several multinational intensive seminars with the same structure of professional workshop were organized by a group of universities without external funding (e.g. through any of the Erasmus programmes). The idea again was exposing the students (and the teachers) to intensive multinational experiences where they need to adopt active roles in developing works and projects as well as interacting with others in multinational teams and present results in front of a large international audience which influences their final grading. The centers involved in these so-called IT Seminars (ITSem) through 2006 to 2010 were Universidad Europea de Madrid (Spain), Lingby Business School (Denmark), Haaga-Helia University of Applied Sciences (Finland) and North Michigan University (USA), also with the participation of Management Center Innsbruck (Austria) in one edition (2008). Each edition combined several topics of especial relevance for being IT professionals covering mobile devices, software testing and requirements, information systems implementation, usability, etc. Teams of students (averaging 3-4 students and 2 teachers per each university) and duration (one week) were smaller than IP due to the absence of external funding. More detailed information of one of these seminars (2006) can be found in [17] including organization of the local University, planification, students selection method, daily schedule, feedback evaluation of the 28 students, and learned lessons. The IT seminars have been celebrated since 2012 (after the first period of editions) with an average of 25-35 participants (students and professors):
- $7^{\text {th }}$ edition $(2012)$ in Spain with Lingby Business School (Denmark), Haaga-Helia University of Applied Sciences (Finland), and Universidad Europea de Madrid (Spain) as participants

- $8^{\text {th }}$ edition (2014) in Helsinki with Lingby Business School (Denmark), Universidad Europea de Madrid (Spain), and Haaga-Helia University of Applied Sciences (Finland)

- $9^{\text {th }}$ edition (2015) in Denmark with Universidad Europea de Madrid (Spain), Haaga-Helia University of Applied Sciences (Finland), HES-SO University of Applied Sciences Western (Switzerland), and Lingby Business School (Denmark).

- $10^{\text {th }}$ edition (2016) the host will be Universidad Europea de Madrid (Spain) with the same participants as $9^{\text {th }}$ edition.

A new Erasmus IP project DOSSEE (https://ipdossee.metropolia.fi/) was approved by EU in 2009 allowing three editions from 2010 to 2012. This time the topic was centered in Open Source Expertise and involved a group of 7 universities:

- Metropolia University of Applied Sciences, Finland

- FH JOANNEUM - University of Applied Sciences, Austria

- Universidad de Alcalá, Spain

- Technickáuniverzita v Kosiciach, Slovakia

- Transport and Telecommunication Institute, Latvia

- University Joseph Fourier, France

- DTU Technical University of Denmark, Denmark

- Università degli Studi di Genova, Italy (only in edition 2010).

The classical scheme of 10 students and 2 teachers during two intensive weeks were again reproduced with a more active activity of projects in multinational teams. A three-folded source of grading was created: local teachers for previous work, intra-team evaluation based on members opinion on the rest's performance and crossteam evaluation based on official presentations at the end of the period (with access to shared repository of documents from each project). In all cases, the working language was English. The selection of students was based on the combination of appropriate command of English and on their technical skills (academic performance) and maturity (normally from $3^{\text {rd }}$ year upwards). Different supporting systems were provided: wiki, collaborative websites, etc. In all the experiences the working scheme includes the following steps:

1) Work in local university as previous preparation for the intensive period. In the official IP programs, this was focused on the development of the first stages of a project (specification, analysis, preliminary design, etc.) while for ITSem was the preparation of presentations and demos about a topic previously selected by teachers. The required effort was equivalent to one full-time week ( $40 \mathrm{hr}$.) and English was used as working language for documents (and normally also for meetings) which have to be shared with the rest in subsequent phase.

2) Intensive period. Depending on the program, it was extended along one (ITSem) or two weeks (IP) combining some lectures and academic activities 
(also including some presentations by professionals), working hours for progressing in assignments or projects and some compulsory social activities organized by the host staff and by local students (visits to museums, city sightseeing, parties, local experiences, etc.). As a rule, students are organized in mixed multinational teams by the teachers, keeping in mind that global professional teams implies one has to be integrated without choosing mates. Sometimes the set of students coming from one university includes students from different nationalities as the school is already having multinational presence in its degrees. The workload was always planned as full time schedule devoted to the program (7-8 hours) with some compulsory social activities after the work agenda, at least on 2 or 3 days of the period. Quite often, students organized themselves in order to devote some extra hours to complete assignments or projects. They wanted to be sure they are ready to present the results at the end of the intensive period. They also arrange additional social common activities after their first contacts with other students from other countries.

3) Evaluation and grading. These experiences were organized as official academic activities which have to lead to credit recognition in each of the universities: this is recommended by Erasmus programme for IP but it was also agreed by universities for ITSem. At the end of the intensive period, there were always some activities, mainly presentations before the whole audience or a part of it, which provide the basis for grading jointly with additional sources of information. The most complete scheme was applied to the last IP where three partial grades were combined for final grade: local work before intensive weeks by local teachers, effort and attitude during teamwork by teammates and final results by other teams based on presentation and documents.

A complete description of one of the seminars of IP DOSSEE (2011) can be found on [18]. Although the focus is on the software project developed by their University team, it includes specific information about how it organized the seminar too.

A similar scheme was reproduced in another Erasmus IP project named E-Discovery which was developed from 2011 to 2013 in three editions in the locations: Amsterdam (The Netherlands), Manchester and Laval (France). The centers were the following:

- Mid-Sweden University (Sweden)

- University of Alcalá (Spain)

- HVA Hogeschool van Amsterdam (Netherlands)

- University of Salford (UK)

- University of Applied Sciences Bonn-Rhein-Sieg (Germany)

- ESIEA - Ecole superieure d'informatique, electronique et automatique (France)

- University of Zagreb (Croatia).

This Erasmus IP was coordinated by HVA and focused on e-discovery understood as computing forensics working with known case studies.
These three intensive international experiences (ItSeminar, IP DOSSEE and IP e-discovery) are the sources of information for our study on the effects and attitudes of ICT students in multinational settings.

\section{Information collected from the intensive experiences}

The series The Collection of information was extensive in all the experiences covered in this article. Of course, sources were really varied and useful given the proximity of teachers and students with the organizers. As an example, apart from the questionnaires whose data are the basis of the results presented in this article, all the experiences included a complete coverage with photographs, reports or even videos of sessions. However, a systematic collection of information was designed to reach a deeper understanding of the ideas of participants as well as the effects of the experience on them, when they work in an international and multinational setting reproducing both academic tasks and professional project activity.

We used questionnaires as method for collecting information combining with direct observation and informal feedback registered in reports during or at the end of each experience. The questionnaires were anonymous to avoid generating a resistance to answer but some general data about the country origin, previous experiences, etc. were requested together with the opinion of students. They were used in a typical pre (before travelling to destination or just before starting it) and post (the last day of the experience) scheme to analyze the effects of the international experience in the perception of participants.

The questions requested not only comments and evaluation about the program and the organization, but also required some auto evaluation of certain skills or attitudes. The questionnaires we used were different but complementary to the ones which were established as compulsory by the European Union, with a fixed set of questions, at the end of each official Erasmus IP program. These compulsory surveys were a requirement stated by the European Union for the final report of each IP.

1) One of the main goals of analysing the experiences was to explore the behaviour of students when exposed to these intensive multinational experiences. Some references in literature have addressed some positive relationships between participation and future orientation to international activity [19], as well as general satisfaction with the multinational experiences [20]. Those should be completed with the influence of collaborative experiences and teamwork for global engineering training [21]. So, one hypothesis to validate was if these experiences might influence students to be more oriented to future international exposure, as well as to longer experiences abroad both for educational or professional purposes. It was also important to know how they perceive the cultural differences, and finding out which skills help to cope with them.

2) It has been confirmed by research that the model of variables which influence students' satisfaction is slightly dependent on the country of origin [19]. However, regarding general satisfaction with these 
experiences, there are not big differences when dealing with European countries. Therefore, the general satisfaction with the experience without country level segmentation will be presented, and the results for each country will be shown only in some few variables in an informal way in order to get a more detailed picture when meaningful.

3) The data collection was organized through two questionnaires: one at the beginning of the seminars, and another at the end. The sample presented here comes from 125 students participating in the feedback and included students from Spain, The Netherlands, Sweden, Norway, Austria, USA, Finland, Slovakia, Latvia, Italy, etc. The diversity leads to small numbers of each nationality which do not allow deeper analysis of results by country.

\section{Results and observations experiences}

As explained before, population of valid respondents included 125 students after requesting information through questionnaire from all participants. The sample was not balanced in gender distribution showing a majority of male gender $(80 \%)$ as usual in IT degrees.The criteria for selection of the students who finally participated in the experiences were similar in all of them: those who had fewer remaining credits to complete the degree (normally enrolled in 3rd or 4th year), capacity of communication in English (interviews with English lecturers or coordinating teachers had to be passed) and a clear motivation to participate checked during interviews with coordinating teachers in each university.

\subsection{Pre-experience questionnaire}

The first questionnaire was delivered before starting the intensive period to check the skills and attitudes related to the international experience. Students were asked to answer $\mathrm{Y} / \mathrm{N}$ about their concerns before starting the seminar. The results in each item were the following:

- Regarding communication skills in English most of respondents reported to have no problem $(43,4 \%)$ with English language. Moreover a 44,2 \% declared they have a specific diploma or certificate of English language skills. Still a $25,5 \%$ answered they have only survival communication skills in English, so that is a problem to be solved in future seminars. More specifically, they were asked about their concerns. The main worry was about presentation in general before an international audience regardless of the language used (39\%) followed by oral communication skills (29\%), and only $10 \%$ were worried about written communication skills.

- About previous experience in other countries, $71 \%$ had travelled abroad before. Many of them had even been using English for communication previously $(77 \%)$ but mostly only for vacation or leisure trips (67\%). Only $22 \%$ were worried about how to organize their daily life in another country.

- Other concerns related to working during the seminar are shown in Fig. 1: the main one was the lack of enough technical skills (36\%), followed by lower values about working in teams ( $6 \%$ ), closer work with teachers $(6 \%)$, or sharing time with foreigners $(11 \%)$.

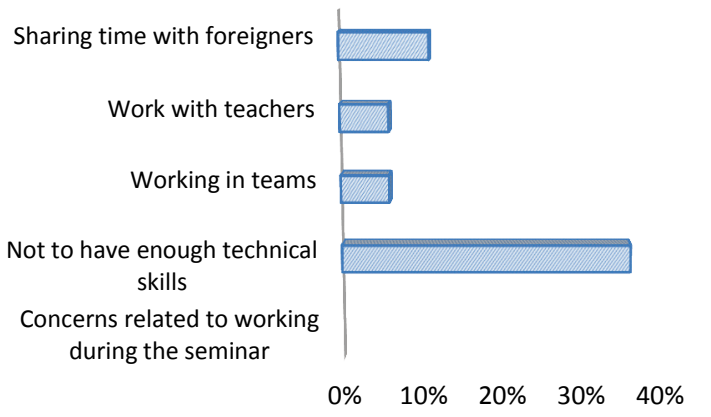

Figure 1 Student's concerns related to working during the seminar

\subsection{Post-experience questionnaire}

General satisfaction with experience in all these international events was really high. As shown in Fig. 2, only $13 \%$ had a slightly negative perception, while it was considered really positive by $56 \%$ and slightly interesting by $31 \%$ of respondents.

Satisfaction was analyzed using basic instruments as questionnaires. We also thought about a bit more complex approach to learn which the most influential factors for satisfaction are by collecting specific evaluation of each activity or characteristics of the programs. The lack of uniformity of all the experiences made these data only valuable for each series of programs (e.g. ITSem, IP DOSSEE, IP e-discovery, etc.): feedback was interesting for teachers to refine the design of the experiences for the subsequent edition, but it is not possible to get general conclusions, applicable to other multinational experiences. Some of the data were included in reports as well as the above mentioned publications $[17,18]$.

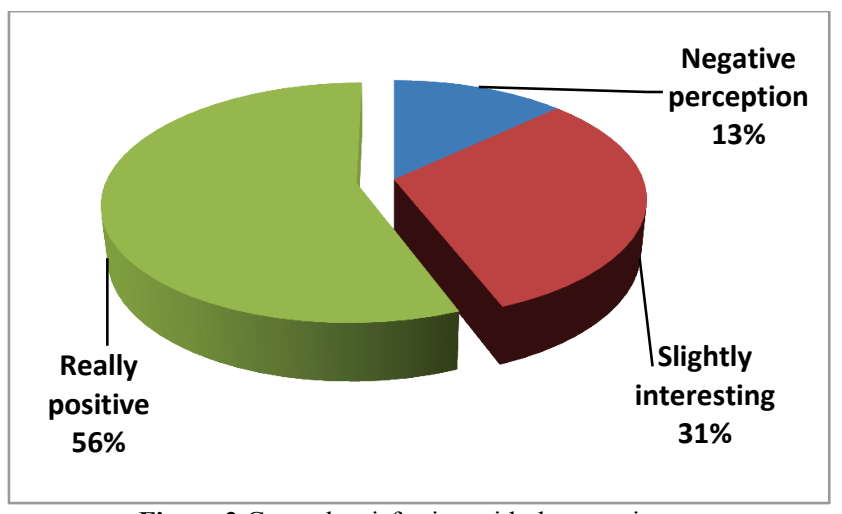

Figure 2 General satisfaction with the experience

However, another question was "Would you recommend your colleagues at your local university to participate in future years in the experience?". The result was clear: 98,3\% would do it and we did not detect any special bias or influence depending on previous level of communication in English or level of international experiences.

To check if the first self-evaluation of their skills was an accurate forecast of the real results, the students were again requested to express their perception of their real 
performance according to the criteria already checked in the pre-test: use of English, technical skills, fears about how to live the experience, etc. (Fig. 3) The results were interesting because once the fear factor disappeared the results were more objective:

- Correlation between concerns previous to the intensive seminar for lack of skills and perceived performance at the end was not clear in the selfevaluation of English communications skills (oral, writing, and presentations): $\sigma=-0,36, \sigma=-0,18$ and $\sigma=0,049$. Given that there were global evaluations of performance per each country which do not invalidate general self-evaluation of students, it was confirmed that uncertainty and fear before facing a multinational experience decreased self-confidence of participants before this intensive period. This also happened regarding the general self-evaluation of English communication skills. However, there was a higher level of correlation in the level of conversation and presentation skills with the fact of holding an English language certificate.

- Again, no special correlation was detected between previous self-evaluation of technical skills, cooperation with foreigners or teachers, and organization of daily life in a foreign country. In general, the experience with teachers from other universities was harder for them than with their teachers and with other students.

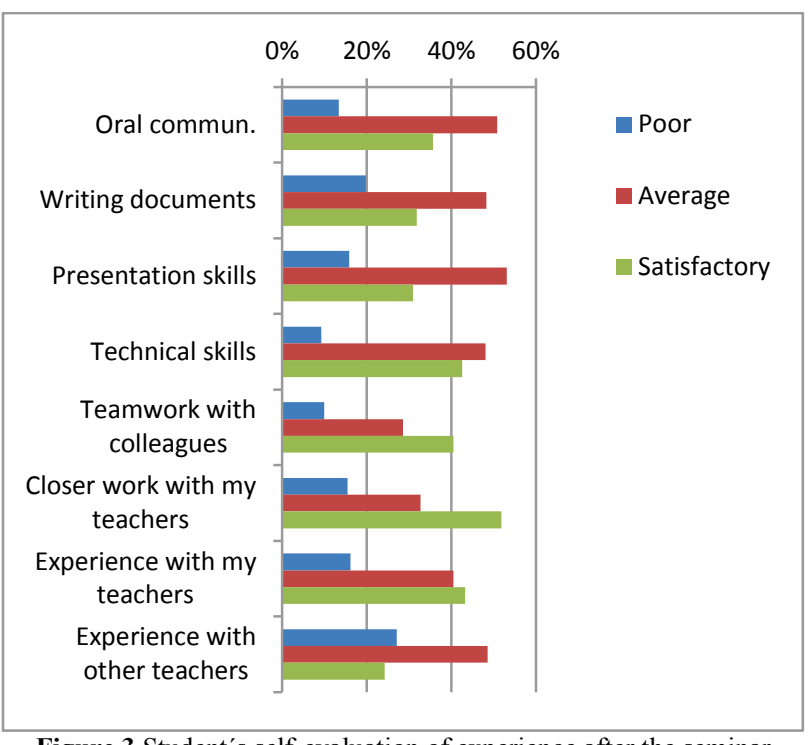

Figure 3 Student's self-evaluation of experience after the seminar

It seems that living a multinational experience helps students to increase their self-confidence in their skills without losing the view of their real capacity. During direct interaction with students and through some of their comments in questionnaires, it was clear that those ones who did not have long or clear experience of working in multinational settings with multicultural teams using English were previously influenced by some uncertainty: this is a reason for promoting this type of intensive experiences as a mechanism for breaking self-imposed limits (before facing real challenges like professional opportunities or longer academic periods for the first time).
Another aspect which was analyzed was the possible effects of the experiences on the perception of students regarding international work, multicultural experience and their motivation to decide on future actions like a longer international exchange, e.g. a semester/year, or going abroad for working:

- "Do you consider you have reached a better understanding of people of other countries and their life style?" was one of the questions: $90,4 \%$ said yes. The same percentage happened when they were asked if this lead to better acceptance of their habits and life style (but there were 2 students who did not match their answers in both questions). It is clear that the declared perception of better understanding and acceptance of the "others" is closely tied to the experiences. There is no correlation of the perception of better understanding and acceptance with the fulfilment of expectations $(\sigma=-0,1)$, which was lower: $73 \%$.

- "Would you spend a semester abroad as Erasmus exchange after this experience?": $87.6 \%$ said yes. Not in all the events but in several ones, the same question was also asked before the intensive period: $8 \%$ less were inclined for a whole semester before the experience. There is an improvement in this direction even keeping in mind there were high percentages of acceptance for this possible experience. This suggests that intensive experiences are a good, cheap and less scaring way for students to be motivated to go abroad and to be open to multicultural and global educational and professional challenges.

As a final remark in studying what was extracted from conversations and direct comments of the students and teachers, it was generally accepted that cooperation was good and treatment and sharing of time with foreign students was really friendly. The students and young people were really flexible enough to adapt their minds and attitudes to reach the highest experiential benefit of the intensive period. The same was not applicable to teachers: multicultural affairs of older people revealed lower degree of flexibility with other colleagues and students of other countries. Some teachers' prejudices on expected behaviour, their rigid concepts about which is the concept of ideal student or the best way to do something were almost the only negative points of the experiences during the intensive period. In fact, this was also perceived by the students, so the satisfaction with teachers of other countries was the item with the lowest score and a symptom of honesty in the answers of students.

\section{Conclusions}

Universities are getting more and more involved in global education activity as internationalization has become a must for professional activities and for society. ICT studies are especially sensitive to this trend as regular activity of professionals requires collaborative teamwork in multinational projects, even in a distributed manner with frequent intensive periods of face to face work. Students and teachers should be prepared for this challenge. 
Although big exchange programs like Erasmus in Europe have facilitated the international experience in the Universities, students are not always decided to be involved in long semesters or years abroad. They need some tryout to gain confidence and to develop their capacity of performance in international multicultural settings, simulating academic and professional scenarios.

In this paper, we have analyzed the effects of participation in intensive multinational exchange programs (like Erasmus Intensive programs, IT Seminars, etc.) to see if they are effective for promoting a better attitude and motivation towards international experiences and professional challenges in multicultural settings. Results confirm improvement in perceptions and attitudes of students towards mobility, overcoming fears before experiences.

The temporary immersion in a multinational setting has been proved as a good strategy to increase acceptance and proclivity towards future and more challenging international activities. The data collected from 125 students from different nationalities showed that these experiences improved the knowledge and acceptance of different cultures and life styles and helped to gain selfconfidence in their own capacities. As a consequence, we suggest promoting short intensive multinational programs as an introduction for developing skills and attitudes of ICT students before being engaged in longer efforts. We also want to remark that teachers should also be involved in this type of programs as a way to improve their capacities and attitudes for a global educational approach: given that they tend to be less flexible than young students, some specific training and progressive exposure for them is also recommendable. In the case of teachers, reported (although limited) benefits of participation in exchange programs could be used as motivation [16].

In this line of action, we are already working in an analysis of which soft skills are most appreciated by teachers and managers in charge of international students to know if cultural patterns are influencing the perception of performance of foreign students. We adopt the idea of soft skills as defined in the Collins English dictionary: "desirable qualities for certain forms of employment that do not depend on acquired knowledge" [22].

Finally, another further work should explore in a more formal way the analysis of the different factors impacting students' perceptions on mobility in intensive periods to generate a model of quality of service to meet students' expectations following ideas similar to the ones in $[23]$.

\section{$7 \quad$ References}

[1] OECD, International Mobility of the Highly Skilled. OECD Pub. Service. 2001. URL: http://www.oecdbookshop.org/ en/browse/title-detail/International-Mobility-of-the-HighlySkilled/?K=5LMQCR2K9FZN. (04.03.2016)

[2] Developing Cross-Cultural Competencies through Global Teams. // Leading Global Teams / Caligiuri, P.; Lundby, K. New York: Springer New York, 2015. pp. 123-139.

[3] Guruz, K. Higher Education and International Student Mobility in the Global Knowledge Economy. State University of New York Press, 2011.
[4] Institute for International Education. Annual report on student exchange. 2015. URL: http://www.iie.org/en/ Research-and-Publications/Open-Doors/Data. (04.03.2016)

[5] Kozina, G.; Dukić, D.; Keček, D. Attitudes of polytechnic students in informatics on the Croatian higher education system, the chosen course of study and study conditions. // Tehnicki vjesnik-Technical Gazette. 21, 2(2014), pp. 359364.

[6] Razack, N. A critical examination of international student exchanges. // International Social Work. 45, 2(2011), pp. 251-265. https://doi.org/10.1177/00208728020450020801

[7] Petcu. D.; Zaharie, D. Experience in Running a Computer Science Master's Programme in English. First Steps towards Internationalization. // Quality Assurance Review for Higher Education. 4, 1(2012), pp. 5-13.

[8] Aguirre, S.; Quemada, J. E-learning Systems Support of Collaborative Agreements: A Theorical Model. // Educational Technology \& Society. 15, 4(2012), pp. 279295.

[9] Xu, X.; Li, H.; Guo, W. A joint multi-country, multi-culture and multi-disciplinary master programme on software engineering plus X. // Proceedings of the 1st ACM Summit on Computing Education in China (SCE '08) / Beijing, 2008, pp. 1-5. https://doi.org/10.1145/1517632.1517640

[10] Groll, E. A.; Krousgrill, C. M.; Meckl, P. H.; Hirleman, E. D. Experiences with Multi-National, Multi-Semester Design Team Projects. // Proceedings of the $36^{\text {th }}$ Frontiers in Education Conference /San Diego, 2006, pp. 13-17. https://doi.org/10.1109/FIE.2006.322341

[11] European Commission. Erasmus student mobility 2004/2005 - Total number of students by home and host country, Directorate-General for Education and Culture Lifelong Learning Programme. 2007. URL: $\mathrm{http} / / /$ ec.europa.eu/education/tools/docs/statistics-ay0405_en.pdf:1.\%20table105.pdf. (04.03.2016)

[12] European Commission. Erasmus Facts, Figures \& Trends. The European Union support for student and staff exchanges and university cooperation in 2012-2013. Directorate-General for Education and Culture Lifelong Learning Programme. 2014. URL: http://ec.europa.eu/ education/library/statistics/ay-12-13/facts-figures_en.pdf. (04.03.2016).

[13] European Commission. The Erasmus programme 2008/2009 - A Statistical Overview. Directorate-General for Education and Culture Lifelong Learning Programme. 2010. URL: http://ec.europa.eu/education/library/ statistics/ay-10-11/report_en.pdf. (04.03.2016.).

[14] González, C. R.; Mesanza, R. B.; Mariel, P. The determinants of international student mobility flows: an empirical study on the Erasmus programme. // Higher Education. 62, 4(2011), pp. 413-430. https://doi.org/10.1007/s10734-010-9396-5

[15] Teichler, U. Temporary study abroad: the life of ERASMUS students. // European Journal of Education. 39, 4(2004), pp. 395-408. https://doi.org/10.1111/j.1465-3435.2004.00193.x

[16] Kerstin, J.; Schomburg, H.; Teichler, U. The professional value of ERASMUS mobility (2009).

[17] Poindexter, S.; Lehtonen, J.; Stenberg, M. Hietala, H. International Student Intensive Seminar in Europe-A Case Study in Learning Innovations for Global Awareness. // The Journal of Learning in Higher Education. 2, 1(2006), pp. 25-32.

[18] Nyborg, M.; Gustafsson, F.; Christensen, J. E. Developing Open Source System Expertise in Europe. // Proceedings of the $7^{\text {th }}$ International CDIO Conference / Copenhagen, 2011, pp. 1013-1024

[19] Downey, G. L. National identities in multinational worlds: engineers and 'engineering cultures'. // International 
Journal on Cont. Engineering Education and Lifelong Learning. 15, 3-6(2005), pp. 252-259.

[20] Escudeiro, N.; Escudeiro, P.; Barata, A.; Lobo, C. Enhancing students team work and communication skills in international settings. // Proceedings of the International Conference on Information Technology Based Higher Education and Training (ITHET) / Kusadasi Izmir, 2011, pp. 1-8.

https://doi.org/10.1109/ithet.2011.6018683

[21] Daniels, M.; Cajander, A.; Pears, A.; Clear, T. Engineering Education Research in Practice: Evolving Use of Open Ended Group Projects as a Pedagogical Strategy for Developing Skills in Global Collaboration. // International Journal of Engineering Education. 26, 4(2010), pp. 1-12.

[22] Collins English Dictionary $12^{\text {th }}$ edition. Collins.co.uk. HarperCollins Publishers Ltd. Retrieved 6 December 2014.

[23] Arambewela, R.; Hall, J. A comparative analysis of international education satisfaction using SERVQUAL. // Journal of services research. Special no. 6(2006), pp. 141163

\section{Authors' addresses}

Luis Fernández, Ph.D., Associate Professor

Universidad de Alcalá, Department of Computer Sciences

Ctra. Madrid-Barcelona, km. 33,6, 28871 Alcála de Henares,

Madrid, Spain

E-mail: luis.fernandezs@uah.es

José Amelio Medina, Ph.D., Assistant Professor

Universidad de Alcalá, Department of Computer Sciences

Ctra. Madrid-Barcelona, km. 33,6, 28871 Alcála de Henares,

Madrid, Spain

E-mail: josea.medina@uah.es

María Teresa Villalba, Ph.D., Associate Professor

Universidad Europea de Madrid, Department of Computer Science

C/Tajo s/n, 28673 Villaviciosa de Odón, Madrid, Spain

E-mail: maite.villalba@universidadeuropea.es

Sanjay Misra, Ph.D., Professor

Atilim University, Ankara, Turkey

Covenant University, Canaanland, Ota, Nigeria

E-mail: ssopam@gmail.com 